\title{
Space Proposed in Accordance with the Usage Patterns and Analysis of the Charging Station Environment of Electric Vehicles
}

\author{
Hwang, Soon-Min ${ }^{*} \cdot$ Kim, Dong-Chan ${ }^{* *}$ \\ * Dept. of Space design, Kyunghee University, South Korea (hsm-95@nate.com) \\ ** Corresponding author, Dept. of Space design, Kyunghee University, South Korea (dckim@khu.ac.kr)
}

\section{A B S T R A C T}

This study analyzed the electric vehicle recharging station status with recharging time limitation due to long waiting time, and figured out the user status by user interviews. And then this study verified the validity of hypothesis in terms of environmental design perspective and suggested layout of recharging station model. 21 recharging stations in Korea and station operation cases of 7 countries were examined. Except for the USA, the reality of electric vehicle recharging station today is the 1st proving stage focusing on the infrastructure construction of electric vehicle recharging station. It focuses on performance of recharging facility, use efficiency and operation environment of electric vehicle. About the effective waiting time of the user to use it should be studied. The current conditions of recharging station are as follows: Lack of independent recharging space, lack of facility that reduces external effect of recharging space, and lack of lounge for users during the waiting time. These three are essential factors constructing a suggesting model after basic layout, which needs proper measurement on the long recharging time and long waiting time. The essential factors are applied to electric vehicle recharging station layout so that users might use 'digital refresh" i.e. lounge and information contents service during the waiting time which provides convenience of recharging and emotional space with users. Such upgrade recharging station environmental model might resolve the burden of long recharging time which may contribute to the popularization of electric vehicles.

(c) 2014 KIEAE Journal

\section{KEYW O R D}

Electric Vehicles,

Recharging Station,

Parking Zone,

Oil Station,

Environment

\section{Introduction}

\subsection{Research Background and Purpose}

Since Kyoto Protocol in 1997 established the mandatory standard and the obligation to cut greenhouse gas emissions, as of 2008 Korea became the world's sixth-largest greenhouse gas emitter among OECD countries with 501 million tons of the gas production annually. ${ }^{1)}$ The research deals with the issues regarding electric vehicles of which importance is rising due to air pollution and the change of energy market, such as the establishment of electric vehicle charging infrastructure ${ }^{2)}$, the operating system of electric vehicle charging facilities ${ }^{3)}$. The purpose of this research, accordingly, is to suggest the master plan for establishing electric vehicle charging facilities, which will be a necessity sooner or later, by studying current state of electric car charging facilities and their users.

\subsection{Research Methods and Format}

This research was conducted in two ways. First, we observed users' behaviors in the electric vehicle charging facilities (charging facilities downward) for 30 minutes, the minimum charging time, through one to one interview. Second, we visited charging facilities to collect the data of the facilities and their environment and to suggest plans to make use of the waiting time.

We selected as our research subjects 21 facilities, which accepted our interview request, out of 188 facilities in Seoul established based on "Electric Vehicle Charging Facility Distribution Projects"4) of Seoul city and "Electric Vehicle Sharing Projects"5) of Ministry of Knowledge Economy. The facilities are located in public parking lots of the district offices, the fire stations and the subway stations. Our interview was conducted for about 4 weeks from November 1st, 2012 to November 29th, 2012 at the facilities and we investigated the facilities by collecting information about the facilities' environment and organized the data into the

1) Ministry of Land, Transport and Maritime Affairs, Transportation Safety Authority, part of National Transportation GHG Emissions Report, December 2010 , pp. $10 \sim 11$

2) Seung ho Han, Byeong yoon. Choi, Trends in electric vehicle charging infrastructure at home and abroad, Power Electronics Society, Vol.5-2;2000.04, pp.38 41

3) Ji seong .Kim, Jun cheol Lee, Woo jong Park, Yeong jun Choi,, Electric Vehicle Charging Infrastructure Operating System, Proceedings of the Summer Institute of Electrical Engineers ; 2011.07.20 22, pp.147-148)

4) Seoul City Hall, the headquarters climate friendly transportation, "Seoul plans electric vehicle charging infrastructure", 2010

5) Seoul City Hall, the headquarters climate friendly transportation, "Seoul plans electric vehicle charging infrastructure", 2010 
tables. The interviewees were 23 men and women who have experiences with both general and electric vehicles and they were interviewed one-to one in person. This is because there are only a few sources with electric vehicle experience in the country where electric vehicles are not yet common for public. Our interview goal was to understand users' behavior during the waiting time for charging and we organized the results into tables.

\section{1) Research Model}

If the long charging time, the weakness of electric vehicles cannot be decreased to the time of general vehicles, we hypothesized that the quality of waiting time would affect the satisfaction of a charging facility and designed the following research model.

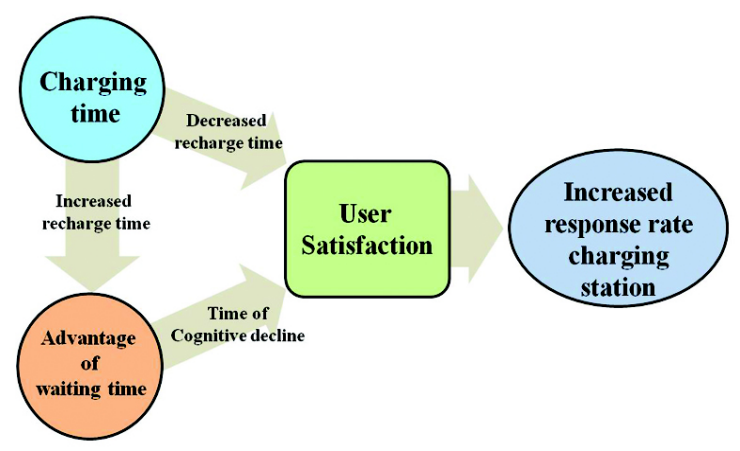

Fig. 1. Research Model

\section{2) Research Hypothesis}

In order to understand the circumstances of current electric vehicle charging facilities and to examine effective ways to make use of the waiting time during the charging, we established the following hypotheses.

A1. The decrease in charging time will increase the preference for electric vehicles and their charging facilities.

A2. The preference will be affected by the service provided by the charging facility.

3) Interview Format

The interview was comprised of one question regarding the

Table 1. Interview items

\begin{tabular}{c|l|c}
\hline Division & \multicolumn{1}{|c}{ Survey items } & Remarks \\
\hline $\begin{array}{c}\text { Charging } \\
\text { environment }\end{array}$ & $\begin{array}{l}\text { Access, security, and cognitive } \\
\text { Installation type / Nearby Facilities } \\
\text { Landscape Environment }\end{array}$ & Provide forms \\
\hline \multirow{2}{*}{ Resting behavior } & $\begin{array}{l}\text { Frequency of use charging stations } \\
\text { Rest in frequency of use, rest the way }\end{array}$ & usage behavior \\
\cline { 2 - 3 } & Complaints, good point, Desire & Improvement \\
\hline $\begin{array}{c}\text { Demographic } \\
\text { Survey }\end{array}$ & Gender, age, occupation & \\
\hline
\end{tabular}

environment of charging and the charging facilities and two questions regarding user resting behaviors at the facilities.

\section{Current status and other considerations}

\subsection{Cases in Countries Overseas}

\section{1) Europe}

The electric vehicle charging facilities in Europe countries such as U.K., Germany, France and Belgium employ the pole-type slow chargers, which we believe is because of unfavorable conditions such as old buildings and narrow streets for setting up high power transmission facilities. The electric vehicle charging facilities in Europe are operated in the street parking lots as is seen in Fig. 2. Their names are 'Juice Point' in U.K., 'RWE' in Germany, 'autolib' in France and 'Elektrobay' (basically the same company as Juice Point) in Belgium and they are fairly noticeable on the streets. ${ }^{6}$ Due to the limited space, there are no space for resting and the type, the shape, the setting environment and the quantities of the chargers are summarized as follows.
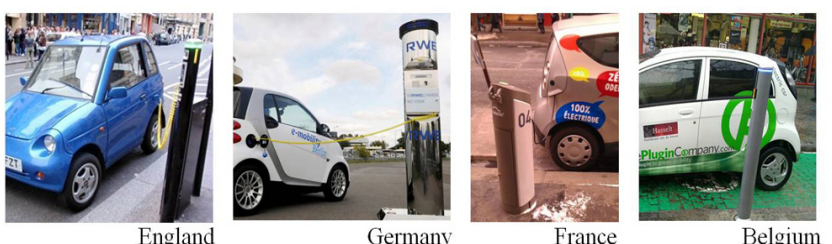

Fig. 2. European countries slow charger

Table 2. Status of the European stations(2012.11)

\begin{tabular}{l}
\hline \multirow{2}{*}{ Country / City } \\
\cline { 3 - 7 }
\end{tabular}

6) Transport for London(TfL) - http://www.tfl.gov.uk, / The Kyunghyang Shinmun, 2010.03.29. Mr Park - http://smile.khan.co.kr, 
2) USA

The type of electric vehicle charging facilities in USA are varied and each local charging facility has its own module according to its surroundings as is seen in Fig 3. Santa Clara, California and Chicago, one of the cities with the most electric vehicle users in USA have applied 'Charge Point' system in operating their facilities.7) Also, depending on its location, some have shelter-type solar energy panel with them to realize environmentally friendly energy. ${ }^{8)}$ Many of charging facilities in Santa Clara are in the form of both shelter-type and bench-type, which we assume is because it has lower building density than other cities. Also, we believe the weather in California affected the facilities to take the shelter or the awning shape. It seems that the location and its surroundings of a charging facility are closely related to its form. Table 3 summarizes what have been discussed above.
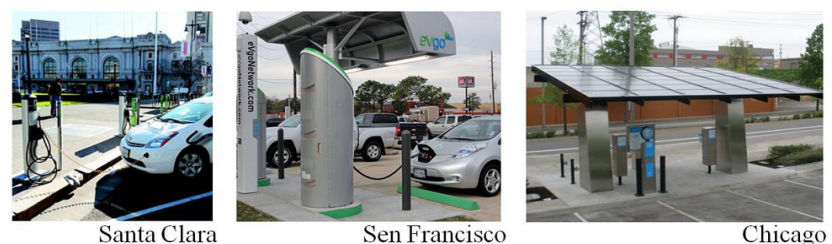

Fig. 3. American region Charger

Table 3. Status of the U.S. regional stations(2012.11)

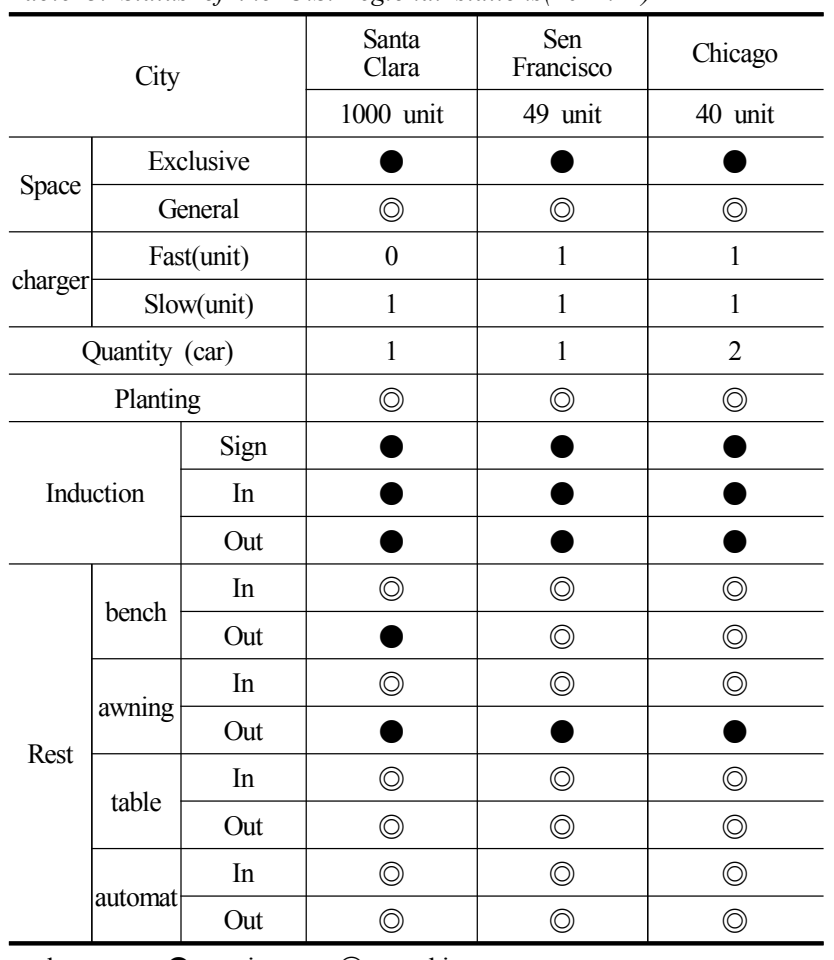

explanatory - $\mathrm{O}$ : existence, ( ) : nothing

7) AP/Newsis, 2012.03.18., KSGA, "Announced a public hearing KS charging system", 2011.02.16.

8) KISTI Mirian, "Global Trends Briefing" , 2011.07.11.
3) Asia

The electric vehicle charging facilities in Japan and China are not common, which is similar to Korea. Therefore, it is premature to discuss the resting and the convenience in the facilities' surrounding $\mathrm{s}^{9}$. It seems that Japan and China are going through examining the operation systems of charging facilities ${ }^{10}$ ) and thus their status doesn't seem so much different than Korean as is seen in Table 4.
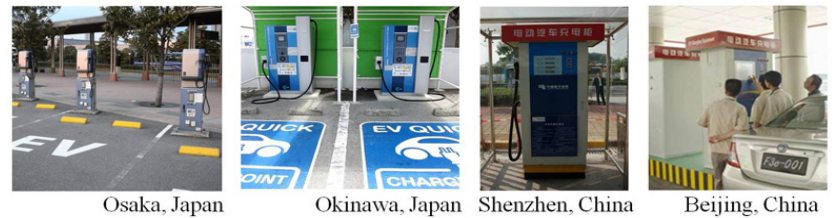

Table 4. Status of Asian regional stations(2012.11)

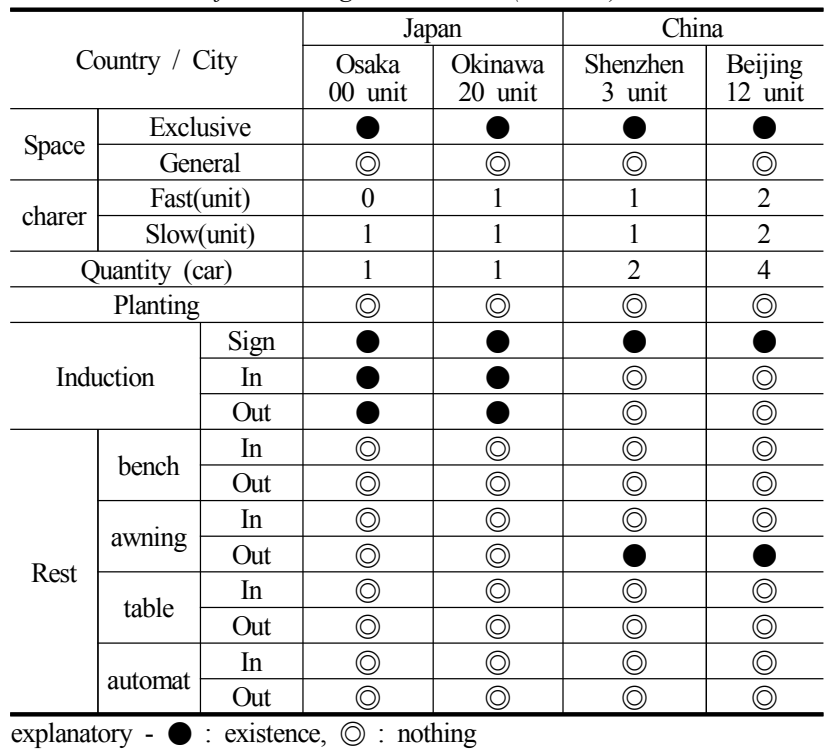

\subsection{Cases in Korea}

As a result of our research on the electric vehicle charging facilities, it turns out that current charging facilities in Korea are part of either government-led distribution projects or testing projects of related companies and thus not sufficient for public.

The research categorized the facility items into 3 types,
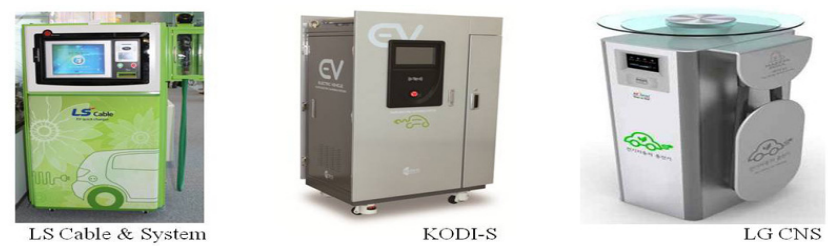

Fig. 5. Status of domestic Charger

9) Digital Times, 2012.09.16, Reporter Mr Lee Hyeong geun bass007@dt.co.kr,

10) The Korea Transport Institute, "Issue Report; electric vehicle development strategy in China and Implications", Vol.16, 2012.07 
charging, introduction and resting and the subcategories were facility type, charging type, quantity, planting and signs. 17 facilities out of 21 has made use of existing parking space whereas 5 including the National Assembly, the Korea Electric Power Corp and GS Caltex, were built originally for the electric vehicle charging. The facilities have both fast and slow chargers and one charger is supposed to charge one vehicle at a time. In cases of facilities built in existing parking lots, facility signs are important, without which it is difficult for users to notice and approach them. Only 9 facilities such as supporting corporations and large grocery chains have facility signs. The 6 facilities located in GS Caltex gas station and parking lots of large grocery chains and GS caltex ones have a good facility sign system associated with gas station signs. The ones in large grocery chains also are equipped with good facility signs linked to existing parking constructs. Since electric vehicle charging requires a waiting time, it is necessary to equip resting area. The most insufficient part of current charging facilities is planting and only 6 facilities have planting and even four of them have it outside of the facilities. Considering the fact that electric vehicles itself are eco-friendly and the charging necessitate the waiting time, planting matched with each facility should be emphasized. In addition, since most of the facilities are built within the public parking lots and don't exist for themselves, it is impossible to secure resting areas solely for the charging facilities. As is seen Table 5, 6, 7, 8, current electric vehicle charging facilities focus on their technology demonstration and thus don't have resting areas yet.

Table 5. Status of electric vehicle charging stations, Seoul(2012.11)

\begin{tabular}{|c|c|c|c|c|c|c|c|}
\hline \multicolumn{3}{|c|}{ Facilities } & \multirow{2}{*}{\begin{tabular}{|c|}
$\begin{array}{c}\text { Ctrl Post } \\
\text { Office }\end{array}$ \\
0 \\
\end{tabular}} & \multirow{2}{*}{\begin{tabular}{|c|}
$\begin{array}{c}\text { Gaehwasa } \\
\text { nyeok }\end{array}$ \\
$\bigcirc$ \\
\end{tabular}} & \multirow{2}{*}{$\begin{array}{c}\text { Changdong } \\
\text { yeok }\end{array}$} & \multirow{2}{*}{\begin{tabular}{|c|}
$\begin{array}{c}\text { Bonghwas } \\
\text { anyeok }\end{array}$ \\
0 \\
\end{tabular}} & \multirow{2}{*}{$\begin{array}{c}\begin{array}{c}\text { Bokjeong } \\
\text { yeok }\end{array} \\
0\end{array}$} \\
\hline \multirow{2}{*}{ Space } & \multicolumn{2}{|c|}{ Exclusive } & & & & & \\
\hline & \multicolumn{2}{|c|}{ General } & 0 & 0 & 0 & 0 & 0 \\
\hline \multirow{2}{*}{ charger } & \multicolumn{2}{|c|}{ Fast(unit) } & 1 & 1 & 1 & 1 & 1 \\
\hline & \multicolumn{2}{|c|}{ Slow(unit) } & 0 & 1 & 0 & 0 & 0 \\
\hline \multicolumn{3}{|c|}{ Quantity (car) } & 1 & 2 & 1 & 1 & 1 \\
\hline \multicolumn{3}{|c|}{ Planting } & (2) & () & (2) & ()) & (2) \\
\hline \multirow{3}{*}{\multicolumn{2}{|c|}{ Induction }} & Sign & (2) & () & (2) & (2) & (2) \\
\hline & & In & () & () & (2) & () & (0) \\
\hline & & Out & (2) & () & (2) & (2) & (0) \\
\hline \multirow{8}{*}{ Rest } & \multirow{2}{*}{ bench } & In & 0 & 0 & 0 & 0 & 0 \\
\hline & & Out & (2) & () & (2) & (2) & (2) \\
\hline & \multirow{2}{*}{ awning } & In & (2) & () & (2) & (2) & (2) \\
\hline & & Out & (2) & (0) & (2) & (2) & (2) \\
\hline & \multirow{2}{*}{ table } & In & (2) & () & () & (2) & (2) \\
\hline & & Out & (0) & () & (2) & (2) & (0) \\
\hline & \multirow{2}{*}{ automat } & In & () & (2) & (2) & (2) & (2) \\
\hline & & Out & (a) & (2) & (a) & (2) & ()) \\
\hline
\end{tabular}

explanatory - 0 : existence, () : nothing
Table 6. Status of electric vehicle charging stations, Seoul(2012.11)

\begin{tabular}{|c|c|c|c|c|c|c|c|}
\hline \multicolumn{3}{|c|}{ Facilities } & Suseoyeok & KEPCO & $\begin{array}{c}\text { KEPCO } \\
\text { South Seoul }\end{array}$ & $\begin{array}{c}\text { GS } \\
\text { Samsung }\end{array}$ & $\begin{array}{l}\text { GS } \\
88\end{array}$ \\
\hline \multirow{2}{*}{ Space } & \multicolumn{2}{|c|}{ Exclusive } & (C) & 0 & 0 & 0 & 0 \\
\hline & \multicolumn{2}{|c|}{ General } & 0 & 0 & 0 & 0 & 0 \\
\hline \multirow{2}{*}{ charger } & \multicolumn{2}{|c|}{ Fast(unit) } & 1 & 1 & 1 & 1 & 1 \\
\hline & \multicolumn{2}{|c|}{ Slow(unit) } & 0 & 4 & 2 & 1 & 1 \\
\hline \multicolumn{3}{|c|}{ Quantity (car) } & 1 & 5 & 3 & 2 & 2 \\
\hline \multicolumn{3}{|c|}{ Planting } & (a) & O & O & (a) & () \\
\hline \multirow{3}{*}{\multicolumn{2}{|c|}{ Induction }} & Sign & 0 & 0 & (a) & 0 & 0 \\
\hline & & In & (2) & (a) & (2) & (a) & () \\
\hline & & Out & (a) & (a) & (a) & (a) & () \\
\hline \multirow{8}{*}{ Rest } & \multirow{2}{*}{ bench } & In & (a) & 0 & 0 & 0 & 0 \\
\hline & & Out & (a) & (a) & (a) & (a) & () \\
\hline & \multirow{2}{*}{ awning } & In & O & O & (a) & (a) & () \\
\hline & & Out & (a) & (a) & (a) & 0 & 0 \\
\hline & \multirow{2}{*}{ table } & In & (a) & (a) & (a) & 0 & 0 \\
\hline & & Out & (a) & (a) & (a) & (2) & () \\
\hline & \multirow{2}{*}{ automat } & In & (a) & (a) & (a) & 0 & 0 \\
\hline & & Out & (a) & (a) & (2) & (a) & () \\
\hline
\end{tabular}

explanatory - : existence, () : nothing

Table 7. Status of electric vehicle charging stations, Seoul(2012.11)

\begin{tabular}{|c|c|c|c|c|c|c|c|}
\hline \multicolumn{3}{|c|}{ Facilities } & $\begin{array}{l}\text { Home } \\
\text { Plus }\end{array}$ & $\begin{array}{l}\text { Home } \\
\text { Plus }\end{array}$ & $\begin{array}{l}\text { Lotte } \\
\text { Mart }\end{array}$ & $\begin{array}{l}\text { Lotte } \\
\text { Mart }\end{array}$ & $\begin{array}{l}\text { E Mart } \\
\text { sung su }\end{array}$ \\
\hline \multirow{2}{*}{ Space } & \multicolumn{2}{|c|}{ Exclusive } & (2) & (2) & (2) & (2) & (2) \\
\hline & \multicolumn{2}{|c|}{ General } & 0 & 0 & 0 & 0 & 0 \\
\hline \multirow{2}{*}{ charger } & \multicolumn{2}{|c|}{ Fast(unit) } & 1 & 1 & 1 & 0 & 0 \\
\hline & \multicolumn{2}{|c|}{ Slow(unit) } & 1 & 1 & 1 & 1 & 1 \\
\hline \multicolumn{3}{|c|}{ Quantity (car) } & 2 & 2 & 2 & 1 & 1 \\
\hline \multicolumn{3}{|c|}{ Planting } & (2) & (a) & (a) & (a) & (a) \\
\hline \multirow{3}{*}{\multicolumn{2}{|c|}{ Induction }} & Sign & 0 & 0 & 0 & 0 & 0 \\
\hline & & In & (2) & (2) & (2) & (2) & (2) \\
\hline & & Out & (a) & (a) & (a) & (a) & (a) \\
\hline \multirow{8}{*}{ Rest } & \multirow{2}{*}{ bench } & In & 0 & 0 & 0 & 0 & 0 \\
\hline & & Out & (2) & (2) & (a) & (2) & (a) \\
\hline & \multirow{2}{*}{ awning } & In & (2) & (2) & (2) & (2) & (2) \\
\hline & & Out & (2) & (a) & (a) & (a) & (a) \\
\hline & \multirow{2}{*}{ table } & In & (a) & (a) & (a) & (a) & (a) \\
\hline & & Out & (2) & (2) & (2) & (2) & (a) \\
\hline & \multirow{2}{*}{ automat } & In & 0 & 0 & 0 & 0 & 0 \\
\hline & & Out & (a) & (a) & (2) & (2) & (2) \\
\hline
\end{tabular}

Table 8. Status of electric vehicle charging stations, Seoul(2012.11)

\begin{tabular}{|c|c|c|c|c|c|c|c|}
\hline & acilities & & $\begin{array}{c}\text { Yeong } \\
\text { deungpo-gu } \\
\text { Office }\end{array}$ & $\begin{array}{l}\text { Nowon-gu } \\
\text { Office }\end{array}$ & $\begin{array}{l}\text { Nam } \\
\text { san } \\
\text { Annex }\end{array}$ & $\begin{array}{c}\text { Seosomun } \\
\text { Annex }\end{array}$ & $\begin{array}{l}\text { Parlia } \\
\text {-ment } \\
\text { House }\end{array}$ \\
\hline Snace & Exclu & & (2) & (C) & (2) & (2) & 0 \\
\hline space & Gene & & 0 & 0 & 0 & 0 & 0 \\
\hline charger & Fast(u & & 1 & 1 & 1 & 1 & 0 \\
\hline narget & Slow( & nit) & 1 & 1 & 3 & 2 & 3 \\
\hline & intity (ca & & 2 & 2 & 4 & 3 & 3 \\
\hline & & & 0 & 0 & 0 & 0 & (2) \\
\hline & & Sign & (2) & (2) & (2) & (0) & (2) \\
\hline $\begin{array}{l}\text { Int } \\
\text { Plant }\end{array}$ & ngion & In & (2) & (a) & (2) & (2) & (2) \\
\hline & & Out & (2) & (C) & (C) & (2) & (2) \\
\hline & hench & In & 0 & 0 & 0 & 0 & 0 \\
\hline & DCIIII & Out & (2) & (2) & (2) & (0) & (2) \\
\hline & awning & In & (2) & (C) & (2) & (a) & (2) \\
\hline Rest & dwinth & Out & (2) & (2) & (2) & (2) & (2) \\
\hline Kest & table & In & (2) & (2) & 0 & (2) & (2) \\
\hline & tavie & Out & (2) & (2) & (2) & (2) & (2) \\
\hline & & In & (2) & (2) & 0 & 0 & (2) \\
\hline & automat & Out & (a) & (a) & (a) & (a) & (a) \\
\hline
\end{tabular}




\subsection{Interview cases}

\section{1) The Characteristics of Interview Sample}

We conducted the one to one interviews to 23 men and women including the participants of 'Electric Vehicle Sharing Projects' by the Ministry of Knowledge and Economy, the users of government electric vehicles provided by Seoul city, the users of corporate electric vehicles of Korea Electric Power Corp and the taxi drivers for the handicapped of Seoul city from November 1th, 2012 to November 30th, 2012. The interview, of which results are summarized in table 9 to 11 , was to figure out electric vehicle charging facility users' behavior during the two types of waiting time, fast charging and slow charging. The interviewee demographics were 5 men in their 20's, 10 men in their 30's, 3 men in their 40's, 3 women in their 20's, 1 woman in her 30's, 1 woman in her 40 's. 11 of them were working for corporations, 6 for governments, 3 were students, 2 were taxi drivers and 1 person was a doctor. 10 of them had experienced electric vehicles through participating in the sharing projects, 6 through governments, 5 through corporation, 2 through taxi driving, and the majority of them except for the two taxi drivers, answered that they had driven them within the city and used fast charging most of the time.

Table 9. Interview sample (2012.11)

\begin{tabular}{|c|c|c|c|c|c|c|}
\hline \multirow{2}{*}{ Division } & \multicolumn{3}{|c|}{ Man } & \multicolumn{3}{|c|}{ Woman } \\
\hline & $27 \sim 29$ & $30 \sim 39$ & 40over & $24 \sim 29$ & $30 \sim 39$ & 40over \\
\hline \multirow{2}{*}{ Personnel } & 5 & 10 & 3 & 3 & 1 & 1 \\
\hline & \multicolumn{3}{|c|}{18} & \multicolumn{3}{|c|}{5} \\
\hline Total & \multicolumn{6}{|c|}{23} \\
\hline
\end{tabular}

Table 10. Interviewed a sample of occupations (2012.11)

\begin{tabular}{c|c|c|c|c|c|c}
\hline \multirow{2}{*}{ Division } & \multicolumn{3}{|c|}{ Man } & \multicolumn{3}{c}{ Woman } \\
\cline { 2 - 7 } & $27 \sim 29$ & $30 \sim 39$ & 40 over & $24 \sim 29$ & $30 \sim 39$ & 40over \\
\hline White Collar & 2 & 7 & - & 1 & 1 & - \\
\hline Doctor & - & - & 1 & - & - & - \\
\hline Official & 2 & 3 & 1 & - & - & - \\
\hline Student & 1 & - & - & 2 & - & - \\
\hline Driver & - & - & 1 & - & - & 1 \\
\hline
\end{tabular}

Table 11. EV usage behavior(2012.11)

\begin{tabular}{c|c|c|c|c|c|c}
\hline \multirow{2}{*}{ Division } & \multicolumn{3}{|c|}{ Man } & \multicolumn{3}{c}{ Woman } \\
\cline { 2 - 7 } & $27 \sim 29$ & $30 \sim 39$ & 40over & $24 \sim 29$ & $30 \sim 39$ & 40over \\
\hline Sharing & 3 & 2 & 1 & 3 & 1 & - \\
\hline Official & 2 & 3 & 1 & - & - & - \\
\hline Company & - & 5 & - & - & - & - \\
\hline Taxi & - & - & 1 & - & - & 1 \\
\hline
\end{tabular}

\section{2) The Analysis of Users Behavior at the Charging Facility}

The analysis of interview results are summarized in the table 12 . The interviewees were asked about 4 issues including inconveniences in using the facilities, users' behavior during the waiting time, things to improve. In cases of slow charging, which takes 6 to 8 hours, since it is highly likely that the users charge their cars after work or during their long off-time and thus there is virtually no waiting time, we didn't include it in our analysis. In terms of waiting time for fast charging, most frequent user behavior was web surfing through smart phones followed by watching DMB, having drinks (coffee, juice and water), smoking, using toilets. The taxi drivers and corporate or government vehicle users answered that they spent the time calculating routes based on the locations of the electric charging facilities, maintaining or washing their vehicles. 19 respondents said that due to the absence of facility signs they had difficulties finding the locations when navigations finished before destinations. Respondents said that it was inside the cars where they web surfed, had drinks and read magazines during the waiting time and the reason they did so seems because there were no resting areas. 20 out of 23 interviewees answered that sitting areas such as lounge style and awning or shelter type should be established. Also, it seems that users' expectations for the waiting time at the charging facilities are high because of their prior similar experiences of the waiting time at resting areas in gas stations ${ }^{11)}$ and auto repair shops.

According to Table 13, 21 out of 23 had decided to stay inside their vehicle and this seems because resting facilities were unavailable. Also, most of those who answered they use their smart phones to kill the waiting time web surfing, watching DMB or using SNS messenger were in their 20's or 30's, which seems because there were very few interview sources in their 40's. It seems that the reason why the use of a smart phone is most frequent regardless of age is because of the lack of killing-time contents for the waiting time. 17 people out of 23 selected having drinks, the third most frequent behavior, for which the use of a vending

Table 12. Stations use problems(2012.11)

\begin{tabular}{c|c|c|c|c|c|c|c}
\hline \multirow{2}{*}{} & \multicolumn{3}{c|}{ Man } & \multicolumn{3}{c}{ Woman } \\
\cline { 3 - 9 } \multicolumn{2}{c|}{ Division } & $\begin{array}{c}20 \\
\text { Age }\end{array}$ & $\begin{array}{c}30 \\
\text { Age }\end{array}$ & $\begin{array}{c}40 \\
\text { Age }\end{array}$ & $\begin{array}{c}20 \\
\text { Age }\end{array}$ & $\begin{array}{c}30 \\
\text { Age }\end{array}$ & $\begin{array}{c}40 \\
\text { Age }\end{array}$ \\
\hline \multirow{4}{*}{$\begin{array}{c}\text { Use } \\
\text { problems }\end{array}$} & Space & 2 & 6 & 1 & - & - & 1 \\
\cline { 2 - 9 } & charge & - & 2 & - & - & - & 2 \\
\cline { 2 - 9 } & Location & - & 5 & - & 3 & 1 & 1 \\
\cline { 2 - 9 } & sign & 4 & 4 & - & 2 & 1 & 1 \\
\hline \multirow{4}{*}{ Use improvements } & Rest area & 5 & 9 & 3 & 2 & 1 & 1 \\
\cline { 2 - 9 } & Silence & 1 & 4 & - & 1 & - & 1 \\
\cline { 2 - 8 } & sign & 3 & 1 & 1 & 1 & - & - \\
\cline { 2 - 8 } & Toilets & 1 & 1 & - & - & - & 1 \\
\cline { 2 - 8 } & bench & 3 & 6 & 1 & 3 & 1 & 1 \\
\cline { 2 - 8 } & awning & 1 & 4 & 1 & 3 & 1 & - \\
\hline & Drinks & 1 & 4 & 2 & 1 & - & 1 \\
\hline
\end{tabular}


Table 13. usage behavior waiting time(2012.11)

\begin{tabular}{|c|c|c|c|c|c|c|c|c|}
\hline \multirow[b]{2}{*}{ Division } & \multirow[b]{2}{*}{ Rest \% } & \multicolumn{3}{|c|}{ Man } & \multicolumn{3}{|c|}{ Woman } & \multirow[b]{2}{*}{ Total } \\
\hline & & $\begin{array}{c}20 \\
\text { Age }\end{array}$ & $\begin{array}{c}30 \\
\text { Age }\end{array}$ & $\begin{array}{c}40 \\
\text { Age }\end{array}$ & $\begin{array}{c}20 \\
\text { Age }\end{array}$ & $\begin{array}{c}30 \\
\text { Age }\end{array}$ & $\begin{array}{c}40 \\
\text { Age }\end{array}$ & \\
\hline Vehicle waiting & 91.3 & 5 & 10 & 3 & 2 & - & 1 & 21 \\
\hline SNS/Game & 34.7 & 1 & 2 & 1 & 3 & 1 & - & 8 \\
\hline Web Surfing & 39.1 & 3 & 5 & 1 & - & - & - & 9 \\
\hline DMB & 26 & 2 & 2 & 2 & - & - & - & 6 \\
\hline Drinks & 82.6 & 4 & 8 & 2 & 3 & 1 & 1 & 19 \\
\hline Smoking & 30.4 & 2 & 3 & 2 & - & - & - & 7 \\
\hline Path search & 34.7 & 3 & 4 & 1 & - & - & - & 8 \\
\hline Wash & 17.4 & - & 2 & 1 & - & - & 1 & 4 \\
\hline Toilets & 13 & 1 & 1 & - & - & - & 1 & 3 \\
\hline
\end{tabular}

machine and a bench is expected. Washing cars and using toilets are excluded from our analysis since they are not exclusive behaviors to the vehicle charging facilities,

\section{3) Research Hypothesis Examination}

The hypothesis A1 "The decrease in charging time will increase the preference for electric vehicles and their charging facilities" assumes that the length of the waiting time affects users' preference for electric vehicles and its charging facilities. The user behaviors during the 30 minutes of waiting time were analyzed based on the data from 21 facilities and 23 interviews, which is summarized in Table $14.91 .3 \%$ respondents answered that the facility needs a separated resting area. $65.2 \%$ respondents wanted a sitting area. $86.9 \%$ the people said that they used a smart phone for web surfing, watching DMB and SNS messenger during the waiting time, which illustrates that users want to spend the waiting time, realistically impossible to reduce, more wisely. In other words, there is a close relationship between the reduction of the charging time and the preference for electric vehicle charging facilities and providing ways to spend the waiting time more effectively will increase the preference.

The hypothesis A2 "The preference will be affected by the service provided by the charging facility" assumes the fact that the service provided by the charging facility to help users to make use of their waiting time better affects the frequency of using the charging facility. According to the interviews, $39.1 \%$ respondents said that vending machines for drinks are needed and $43.4 \%$

Table 14. Frequency of station facilities(2012.11)

\begin{tabular}{c|c|c}
\hline Division & $\%$ & Remarks \\
\hline Sign & $43.4 \%$ & Stations need to sign \\
\hline induction & $52.1 \%$ & Induction charging port needs \\
\hline charge Area & $43.4 \%$ & Need a parking space separated. \\
\hline Rest area & $91.3 \%$ & No rest area \\
\hline bench & $65.2 \%$ & No bench in the station \\
\hline awning & $43.4 \%$ & No awning in the station \\
\hline automat & $39.1 \%$ & No automat in the station \\
\hline Silence & $30.4 \%$ & No silence in the station
\end{tabular}

interviewees answered that the facility needs an awning area. Also, $82.6 \%$ said that they have drinks while waiting and $86.9 \%$ said they spent time using their smart phones. These facts illustrate that the facility itself is not providing any subsidiary facilities. If additional services become available from the facility, it is likely that the electric car charging will be preferred. To sum up, as a result of the analysis of the interview responses, the two hypotheses above seem to be valid.

\section{Proposal for Electric Vehicle Charging Facility Model}

We discussed through the table 12,13, 14 the factors for the effective time use during the waiting time, which leads to the satisfaction of electric vehicle charging facilities. The conclusions were arranged into two, the charging factor and the resting factor, which we took into consideration for the proposal for electric vehicle charging facility model. Also, we suggest "Digital Refresh Space" where the users can rest and enjoy the digital services provided during the waiting time in pleasant atmosphere.

\subsection{Plans for Creating a Pleasant Customer Environment}

We designed a specific plan for customer environment at the charging facilities based on the data arranged on Table 3, 5, 6, 7, 8 . In terms of layout, we reached a conclusion that the layout of both-sided street is the best out of 12 gas station layouts considering the waiting time, the very characteristic of electric vehicle charging, and the conditions of street locations and there will be the charging area, the signs, and the induction area. Charging area will have at least 4 fast charging ports near the entrance and the exit and 10 slow charging ports at the center of the floor so that it can keep a high charging turnover ratio against its area and the smooth flow of human traffic. Signs here will be pole-shaped sign by which users can locate the facility location from the streets nearby. Induction areas are for protecting vehicles from collision caused by the overlapping of pedestrians and vehicles while they enter into the charging area. There will be the

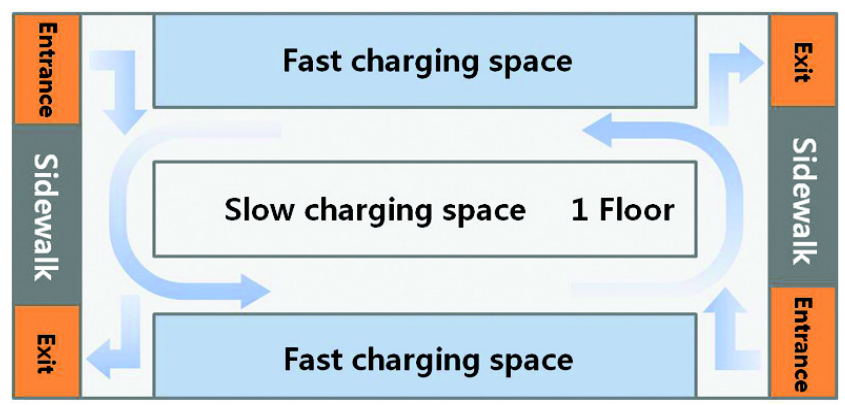

Fig. 6. Station layout model 
main building, two-stories, steel-structured, which will be located at the center of the facility and the first floor will be used as a open charging area. The second floor will be a lounge for resting with $360^{\circ}$ view where users can watch their vehicles being charged and enjoy the view at the same time. There will be a lounge, a management office and a sanitary room on the second floor.

\subsection{Plans for Resting Areas at Charging Facilities}

We have designed the plans for the resting area based on the data from the interviews, which are presented on Table 12, 13, 14. The plans are comprised of tangible services and intangible services. Intangible services refer to informative contents provided through users' vehicle or digital devices on the premise that wifi is available whereas tangible services include the facilities such as awnings, benches, tables and vending machines and planting environment including shade and sound insulation. Planting is divided into two, planting for rest and planting for functioning. Planting for rest uses ground cover plants to divide blocks and trees to provide shades. Plants and trees also can be put near chargers and outside fences for insulating noises from chargers.

\section{Conclusion}

According to this research which studied cases of Korea as well as 7 foreign countries, electric vehicle charging facilities in most countries except for USA are undergoing examination and demonstration phase, focusing on establishing infrastructures and operation systems. The service facilities or operation systems for improving the quality of user waiting time rarely exist. Therefore, we came up with 3 factors affecting the quality of user waiting time, which are charging area, resting area and user available contents and these are the areas for which the improvements can be made.

The three factors above were categorized to the facility type, charging type, quantity of chargers, planting and signs of the charging facilities and we studied cases of each country based on the category and summarized the results in Table 3 for USA and Table 5, 6, 7, 8 for Korea. Also, we interviewed the users and summarized the results on Table 12, 13, 14. Based on them, we found out that our original hypotheses, the satisfaction of the charging facilities will be increased if users can be provided better services, are valid and thus we were able to make our proposals for customer environment.

Our research is significant in that our proposals for creating electric vehicle facility environment in a way that users can be more satisfied with their time spent there can be a basis of improving electric vehicle industry. However, since we are in the transition stage where the electric vehicle charging infrastructure and the technology for the battery of electric vehicle are still developing, possibly into unexpected direction, its significance can be diluted.

\section{References}

[1] Ministry of Land, Transport and Maritime Affairs, Transportation Safety Authority, part of National Transportation GHG Emissions Report, December 2010.12. pp.10-11

[2] Hae. Hyeok. Choi, Gas station construction Guidebook ; future planning, 1993

[3] Climate friendly transport division of Seoul City Hall, Seoul City electric vehicle charging Infrastructure planning, 2010

[4] Seung ho Han, Byeong yoon. Choi, Trends in electric vehicle charging infrastructure at home and abroad, Power Electronics Society, Vol.5-2 ; 2000.04, pp.38 41

[5] Ji seong .Kim, Jun cheol Lee, Woo jong Park, Yeong jun Choi, Electric Vehicle Charging Infrastructure Operating System, Proceedings of the Summer Institute of Electrical Engineers ; 2011.07.20 22, pp.147-148 